\title{
Prevalence and risk factors for asthma among children aged $0-14$ years in Hangzhou: a cross-sectional survey
}

\author{
Dan Xu1, Yingshuo Wang ${ }^{1}$, Zhimin Chen ${ }^{1 *}$, Shuxian Li', Yungai Cheng ${ }^{1}$, Li Zhang ${ }^{2}$ and Lingzhi Zhao ${ }^{3}$
}

\begin{abstract}
Background: Asthma is a global problem. Prevalence varies among different countries and cities. We aimed to obtain the prevalence, describe the characteristics, and discover factors that may relate to asthma in Hangzhou.

Methods: This cross-sectional study was conducted in Hangzhou. The subjects were children aged 14 years and younger. A control group of non-asthma children that matched in age and sex with each asthmatic patient was also randomly selected and interviewed. International Study of Asthma and Allergies in Childhood and National Epidemiology study of Asthma and Allergies in China questionnaires were used in this survey.

Results: We have questionnaired 13,877 children, and 665 (4.8\%) children were diagnosed asthma. The guardians regarded the cost of asthma management affordable in $49.4 \%$, tolerable in $46.9 \%$, and intolerable in $3.7 \%$. Both guardians and children have been absent from work or school due to children's asthma.

Respiratory tract infection was the most common trigger of asthma attacks (85.1\%). Other common causes included cold air, house dust, exercise, fish and shrimp, pollen, and et al. Interestingly, we also found in children 6 years and older, some triggers happened more than that in children 5 years and younger. Those factors included exercise, emotional changes, house dust, pollen, renovation works in the home, mosquito-repellent incense and pets (all the $p$ values were $<0.05$ ). We compared some factors may relate to asthma development. Higher percentage of family history of asthma, personal history of allergy (atopic dermatitis, drug allergy and food allergy), comorbidities (allergic rhinitis, sinusitis, adenoidal hypertrophy, and urticaria), caesarean birth and complications ever happened during pregnancy were discovered in asthma children than in non-asthma children (all the $p$ values were $<0.05$ ). Exclusive breastfeeding within first 6 months and keeping animals had higher percentage in non-asthma children than in asthma (both the $p$ values were $<0.05$ ). Inhaled corticosteroid (ICS)/ICS + long-acting beta2 agonists (LABA) was applied to $46.2 \%$ of patients. Traditional Chinese medicine (TCM) was used in $44.2 \%$ of asthma children, while leukotriene receptor antagonist (LTRA) was used in $36.4 \%$ of them. The adherence scored higher in TCM than in ICS/ICS + LABA $(P=0.003)$ and LTRA.
\end{abstract}

Conclusions: In conclusion, we conducted an epidemiology study in Hangzhou. The prevalence of childhood asthma was $4.8 \%$. Asthma was an economic and social burden to both children and guardians. Risk factors of asthma development may include caesarean birth, personal history of allergy and concomitant allergic diseases. Exclusive breastfeeding within first 6 months and keeping animals might be protecting factors. TCM was really popular in China besides ICS/ICS + LABA and LTRA.

Keywords: Asthma, Children, Epidemiology, Prevalence, Trigger, Risk factor, Inhaled corticosteroid, Exclusive breastfeeding

\footnotetext{
* Correspondence: drchenzm@163.com

'Department of Pulmonology, The Children's Hospital of Zhejiang University

School of Medicine, 3333 Binsheng Road, Hangzhou 310003, Zhejiang

Province, China

Full list of author information is available at the end of the article
} 


\section{Background}

Asthma is characterized by variable symptoms of wheeze, shortness of breath, chest tightness and/or cough, and by variable expiratory airflow limitation, causing poor quality of life, emotional disorders, missing of schooling days and parents' working days, and economic burdens. It is a common, chronic respiratory disease affecting 1-18\% of the population in different countries [1]. Prevalence varies among different countries and cities. The prevalence of childhood asthma in China increased from $0.93 \%$ in 1990 to $1.54 \%$ in 2000 [2]. However, exact date on prevalence of asthma in Hangzhou has not been reported yet. In this study, we aimed to obtain the prevalence of childhood asthma in Hangzhou, describe the characteristics of childhood asthma, and discover factors that may relate to asthma in Hangzhou.

\section{Methods}

This cross-sectional study was conducted in Hangzhou, the capital of Zhejiang Province in the southeast coast of China. The predetermined sample size was 12,000 subjects, calculating from prevalence of $1.54 \%$ in 2000 [2]. The subjects were children born from 1st, July, 1996 to 30th, June, 2010, and living in Hangzhou at least half a year for children older than 6 months, or lived in Hangzhou since born for children younger than 6 months. We randomly selected two communities, fourteen kindergartens, five primary schools, and four junior middle schools using stratified cluster sampling method (Fig. 1).

International Study of Asthma and Allergies in Childhood (ISAAC) and National Epidemiology study of Asthma and Allergies in China (NEAAC) questionnaires were used in this survey. In the first stage, the ISAAC questionnaires were filled in by all the children or their parents from selected communities, kindergartens, primary schools, and grade one in junior middle schools. If any of the answers to questions of "wheeze, ever", "wheeze, last 12 months", "he, he' sound, last 12 months", or "diagnosis of asthma, ever" were positive, the children were included as possible asthma patients. They were identified immediately by doctors on spot or called back by phone to doctors in the hospitals in charge of this investigation to make sure the diagnosis of asthma according to Global Initiative for Asthma (GINA) 2010 [3].

In the second stage, asthma patients were interviewed again. In-depth questionnaires (NEAAC questionnaire) were filled in by investigators. In addition, a control group of non-asthma children that matched in age and sex with each asthmatic patient individually was also randomly selected and interviewed. If the selected control child was not interviewed because of guardian's refusal or other reasons, a second control would be selected and interviewed. NEAAC questionnaire were completed by investigators. The Survey started in September 2010 and finished in April 2011.

The study was approved by the Ethics Committee of Children's Hospital, Zhejiang University School of Medicine. Each questionnaire was approved by the child's guardian. Investigators were doctors or medical students, who were trained before the program. The questionnaires were reviewed in completeness and logicality, and were demanded to be revised properly by interviewing again.

Data were double entered using epi-info system. Data skewed distributed were expressed as medians (25th75 th interquartile ranges). Data normal distributed were expressed as mean \pm standard deviation. McNemar test was applied for data comparison between asthma and control groups. Mann-Whitney U test was applied for quantitative data comparison between subgroups in asthma children. Chi-square test was applied for qualitative data comparison between subgroups in asthma children. Variables were considered statistically significant at $P$ values of less than 0.05 by using two-sided tests. Data were analyzed by SPSS 19.0 (SPSS Inc., USA).

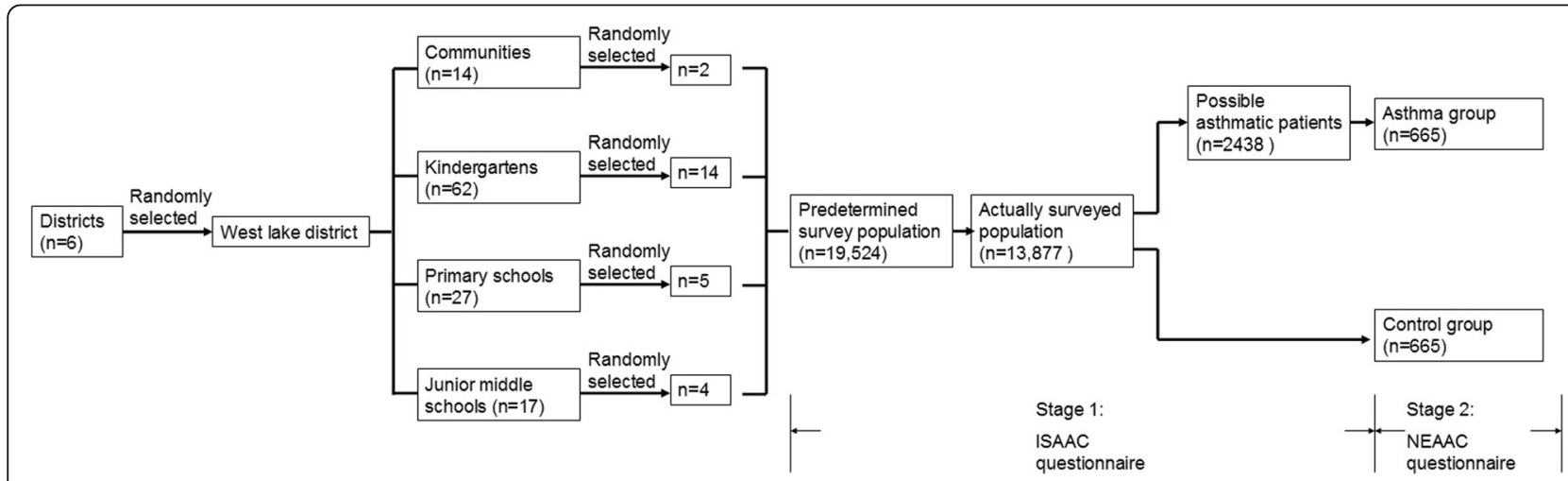

Fig. 1 The sampling and investigation procedure: In the sampling stage, we firstly randomly selected one district, then randomly selected two communities, 14 kindergartens, five primary schools, and four junior middle schools. International Study of Asthma and Allergies in Childhood (ISAAC) and National Epidemiology study of Asthma and Allergies in China (NEAAC) questionnaires were used in stage 1 and stage 2 investigations, respectively 


\section{Results}

\section{Prevalence of childhood asthma}

We have actually questionnaired 13,877 children. A total of 2438 possible asthma patients were selected and 665 (4.8\%) children were diagnosed asthma. Among asthma children, 34 (5.1\%) children were diagnosed cough variant asthma. The male to female ratio was 1:0.58 (420:245). The mean age was $6.9 \pm 2.9$ year. The prevalence of asthma children was higher in boys than that in girls in some ages (Fig. 2). Asthma children were divided into two groups, $0-5$ years $(n=210), 6-14$ years $(n=455)$.

A total of 665 children matched 1:1 in gender and age with each asthma child composed the control group.

\section{Economic and social impact}

We investigated asthma-related expenditure, which included all the expenditures spent on medication and devices, scheduled and unscheduled medical consults, hospitalization, blood and diagnostic tests, education, and lost productivity for the caretaker of asthmatic children, et al. Families spent less than 2000 yuan (41.9\%), 2000-5000 yuan (32.9\%), 5000-10,000 yuan (18.9\%), 10,000-30,000 yuan (5.4\%) and more than 30,000 yuan $(0.9 \%)$ in the year of spending most on asthma-related expenditures. The family yearly incomes were less than 60,000 yuan (14.2\%), 60,000-120,000 yuan (44.5\%), 120,000-240,000 yuan (25.15\%) and more than 240,000 yuan (16.2 \%). The guardians regarded the cost affordable in $49.4 \%$, tolerable in $46.9 \%$, and intolerable in $3.7 \%$. Both guardians and children have been absent from work or school due to children's asthma (Fig. 3). Fortunately, none of the children was suspended from school for asthma. About $82.2 \%$ of these children attended physical education classes normally. However, $17.3 \%$ of them took part in $\mathrm{PE}$ classes selectively while $0.5 \%$ never attended PE classes.

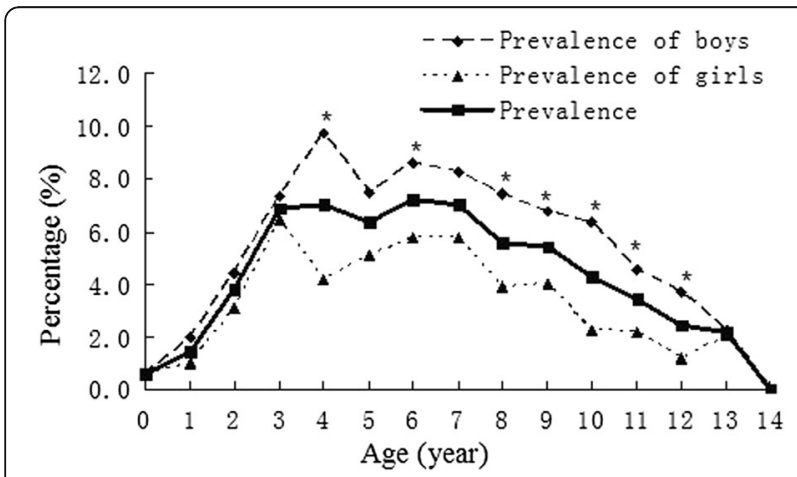

Fig. 2 The prevalence of asthma children: The prevalence of asthma children was high in age 3 to 7. Prevalence of boys was higher than that of girls in age 4, 6, 8, 9, 10, 11 and 12, marked with an asterisk (all the $P$ values were $<0.05$ )

\section{Clinical characteristics and triggers}

In this study, the most common symptom was wheezes (91.1\%), followed by cough (85.4\%), shortness of breath (34.3\%), nocturnal waking (16.8\%), and chest tightness (16.1\%).

In $85.1 \%$ asthmatic children, respiratory tract infection was a trigger of asthma attacks. Other causes included cold air (53.1\%), house dust (20.3\%), exercise (14.6\%), fish and shrimp (14.0\%), pollen (11.1\%), et al. (Table 1). Interestingly, we also found in children 6 years and older, some triggers happened more than that in children 5 years and younger. Those factors included exercise $(16.9 \%$ vs. $9.5 \%$, $p=0.012)$, emotional changes $(4.8 \%$ vs. $1.4 \%, p=0.032)$, house dust ( $23.1 \%$ vs. $14.3 \%, p=0.009)$, pollen ( $13.6 \%$ vs. $5.7 \%, p=0.003)$, renovation works in the home $(11.0 \%$ vs. $3.8 \%, p=0.002)$, mosquito-repellent incense $(6.4 \%$ vs. $2.4 \%, p=0.030)$, and pets $(4.4 \%$ vs. $1.0 \%, p=0.021)$. Five kinds of triggers were inhaled causes.

\section{Risk factors for asthma development}

We compared some factors may relate to asthma development (Table 2).Higher percentage of family history of asthma, personal history of allergy (atopic dermatitis, drug allergy and food allergy), and comorbidities (allergic rhinitis, sinusitis, adenoidal hypertrophy, and urticaria) were discovered in asthma children than in non-asthma children (all the $P$ values were $<0.05$ ).

Additionally, higher percentages of caesarean birth and complications ever happened during pregnancy were found in asthma than in non-asthma (both the $P$ values were $<0.05$ ).

Exclusive breastfeeding within first 6 months and keeping animals, including cats, dogs, birds, pigs, horses, cows, et al. had higher percentage in non-asthma children than in asthma (both the $P$ values were $<0.05$ ).

\section{Current situation of asthma therapy}

The therapies ever used as controller treatment were inquired. On the top of the list, inhaled corticosteroid (ICS) or ICS + long-acting beta 2 agonists (LABA) was applied to $46.2 \%$ of patients. As Chinese people, traditional Chinese medicine (TCM) using in asthma patients was the second most frequently used (44.2\%). And the third one was leukotriene receptor antagonist (LTRA) (36.4\%). Some have tried desensitization therapy (7.2\%). The ages of patients who ever used LTRA, ICS/ICS + LABA, TCM and desensitization therapy were $6.7 \pm 2.9,7.0 \pm 2.8,7.4 \pm 3.0$, and $8.3 \pm 2.6$, separately. Significant statistical differences were found in ages between every two controller groups (all the $P$ values were $<0.05$ ). Although patients ever used desensitization therapy seemed to have more proportion of more than 30,000 yuan (12.5\%) of the most expensive yearly cost of asthma (Fig. 4), we did not found any 


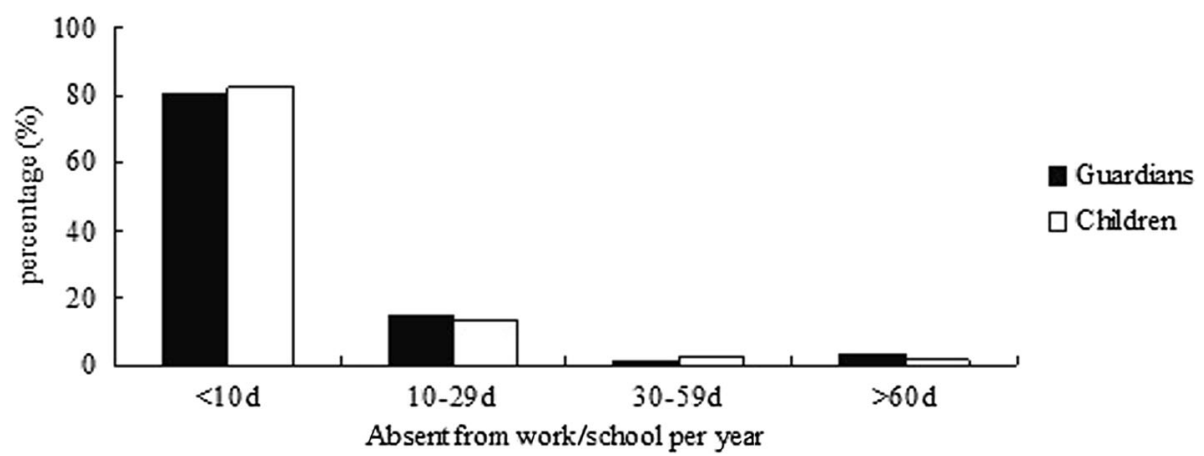

Fig. 3 The percentage of different days absent from work/school: Both children and guardians are absent from work or school due to children's asthma

Table 1 The triggers of childhood asthma in Hangzhou

\begin{tabular}{|c|c|}
\hline Triggers & Percentage (\%) \\
\hline \multicolumn{2}{|l|}{ Daily activities } \\
\hline Respiratory tract infection & 85.1 \\
\hline Cold air & 53.1 \\
\hline Exercise & $14.6^{\mathrm{a}}$ \\
\hline Tied & 7.1 \\
\hline Emotional changes & $3.8^{\mathrm{a}}$ \\
\hline \multicolumn{2}{|l|}{ Inhaled causes } \\
\hline House dust & $20.3^{\mathrm{a}}$ \\
\hline Pollen & $11.1^{\mathrm{a}}$ \\
\hline Renovation works in the home & $8.7^{\mathrm{a}}$ \\
\hline Smoke & 7.8 \\
\hline Paint & 6.8 \\
\hline Moldy smell & 6.8 \\
\hline Odor of cooking oil & 6.2 \\
\hline Mosquito-repellent incense & $5.1^{\mathrm{a}}$ \\
\hline Pets & $3.3^{\mathrm{a}}$ \\
\hline Perfume & 3.0 \\
\hline Disinfectant & 0.9 \\
\hline \multicolumn{2}{|l|}{ Food and medicine } \\
\hline Fish and shrimp & 14.0 \\
\hline Egg & 4.2 \\
\hline Milk & 3.5 \\
\hline Peanut & 2.0 \\
\hline Other nuts & 1.5 \\
\hline Fruit & 1.2 \\
\hline Beans & 1.1 \\
\hline Wheat & 0.6 \\
\hline Vegetables & 0.6 \\
\hline Aspirin & 0.3 \\
\hline Others & 3.8 \\
\hline
\end{tabular}

an children 6 years and older, those triggers happened more than that in children 5 years and younger $(P<0.05)$ significant statistical differences among these controller groups (all the $P$ values were $>0.05$ ).

Adherence was assessed by parents using a scale from 0 to 10 points, which indicating not following doctor's advice at all to completely following doctor's advice. For ICS/ICS + LABA, TCM, LTRA, and desensitization therapy, the adherence scored 10 (8-10), 10 (10-10), 10 (8$10)$ and 10 (9-10), respectively. Data were expressed as medians (25th-75th interquartile ranges). We also found the adherence scored higher in TCM than in ICS/ICS + LABA $(P=0.003)$ and LTRA $(P=0.006)$. No statistical significance was found between other groups.

We explored some factors which we think may affect adherences of different therapies. Those factors included maternal or paternal education and income. We found only maternal education was related to adherence of ICS. Mothers holding college or above degrees had poorer adherence of ICS than those holding middle school or below degrees $(P=0.021)$. Maternal education did not affect adherences of other therapies. Paternal education and monthly income was not related to adherence of asthma medicine (all the $P$ values were $>0.05$ ).

We also questionnaired reasons for not following doctor's advice. Worrying about potential adverse effects (25.1\%) was the reason on the top of the list. However, only $2.7 \%$ of patients actually showed adverse effects, such as uncomfortable in throat or mycotic stomatitis. No major adverse effects or mortality occurred in our study. The second reason was parents believing it was the time to cease medicine for well-controlled asthma (24.8 \%) (Table 3).

\section{Discussion}

In this study, we found the prevalence of childhood asthma was $4.8 \%$ in Hangzhou. This data was higher than the nationwide prevalence of $1.54 \%$ about 10 years ago [2]. The prevalence of asthma was highest in children aged 3 to 7 in this study (Fig. 2). High prevalence is related to high incidence. Prevalence and incidence of asthma was reported differently in different studies. About $80 \%$ of asthma has onset by age 5 years [4]. 
Table 2 Factors may relate to asthma

\begin{tabular}{|c|c|c|c|}
\hline & Asthma $^{a}$ & Non-asthma ${ }^{a}$ & $P$ value \\
\hline \multicolumn{4}{|l|}{ Family history } \\
\hline Asthma in parents & $10.1(67 / 665)$ & $1.7(11 / 665)$ & $<0.001$ \\
\hline \multicolumn{4}{|l|}{ Birth history } \\
\hline Preterm birth & $9.5(31 / 326)$ & $7.1(46 / 644)$ & 0.101 \\
\hline Caesarean birth & $62.6(201 / 321)$ & $45.7(297 / 650)$ & $<0.001$ \\
\hline Complications during pregnancy & $23.6(109 / 461)$ & $14.0(64 / 458)$ & $<0.001$ \\
\hline Infections during pregnancy & $2.8(13 / 462)$ & $0.9(4 / 458)$ & 0.057 \\
\hline \multicolumn{4}{|l|}{ Past history } \\
\hline Exclusive breastfeeding & $51.2(166 / 324)$ & $63.2(405 / 641)$ & 0.002 \\
\hline Hospitalization during neonatal & $14.0(65 / 463)$ & $12.9(59 / 458)$ & 0.634 \\
\hline Drug allergy & $51.9(136 / 262)$ & $10.3(68 / 658)$ & $<0.001$ \\
\hline Food allergy & $13.6(53 / 389)$ & $6.5(43 / 663)$ & 0.001 \\
\hline Atopic dermatitis & $37.1(93 / 251)$ & $4.3(28 / 658)$ & $<0.001$ \\
\hline \multicolumn{4}{|l|}{ Comorbidities } \\
\hline Allergic rhinitis & $79.0(319 / 404)$ & $11.2(74 / 658)$ & $<0.001$ \\
\hline Sinusitis & $26.2(56 / 214)$ & $4.6(30 / 657)$ & $<0.001$ \\
\hline Adenoidal hypertrophy & $40.6(99 / 244)$ & $2.9(19 / 657)$ & $<0.001$ \\
\hline Urticaria & $47.5(135 / 284)$ & $9.6(63 / 658)$ & $<0.001$ \\
\hline \multicolumn{4}{|l|}{ Indoor environment } \\
\hline Renovation works in the home after child's birth & $47.7(155 / 325)$ & $35.8(224 / 626)$ & 0.060 \\
\hline Carpet using & $8.4(27 / 322)$ & $6.8(43 / 632)$ & 0.551 \\
\hline House plants & $44.7(144 / 322)$ & $46.0(294 / 639)$ & 0.335 \\
\hline House animals & $9.2(30 / 325)$ & $15.0(97 / 647)$ & 0.013 \\
\hline
\end{tabular}

${ }^{\mathrm{a}}$ Data were expressed as percentage (\%) (number of positive children/number of children had data )

Incidence of asthma was high in children aged 1 to 9 in a study [5]. In general, incidence rates are higher in children below 5 years $[4,6]$. It is worth noting that the diagnostic criteria in the above literatures were not the same. Prevalence or incidence of a disease is based on its diagnosis. It may be difficult to make a confident diagnosis of asthma in children 5 years and younger, because episodic respiratory symptoms such as wheezing and cough are also common in children without asthma [1]. Because of this uniqueness, GINA always made 'diagnosis and

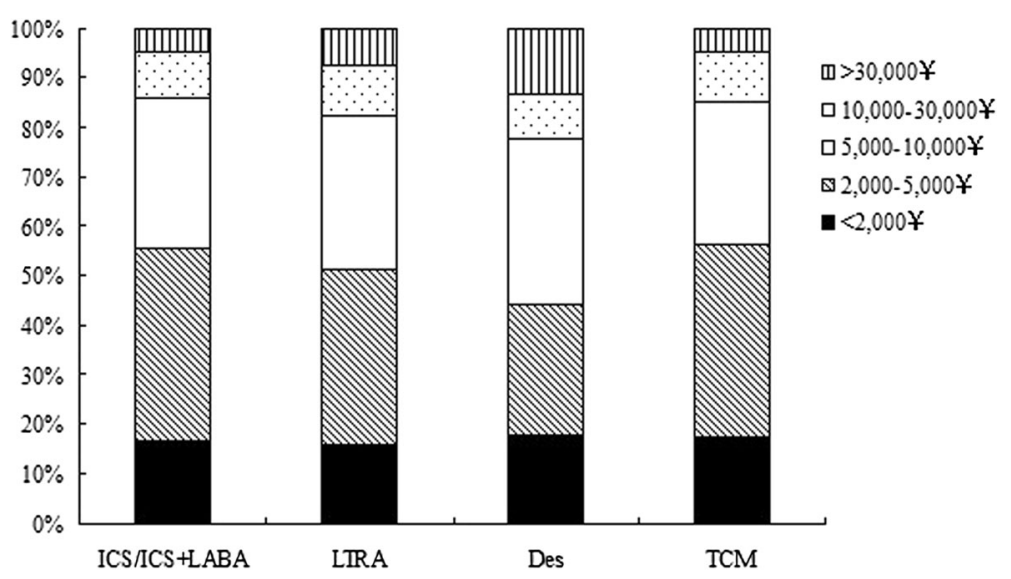

Fig. 4 The most expensive yearly cost of asthma in different therapies ever used as controller treatment. Data were expressed as proportions. No significant statistical differences were found between each two controller groups (all the $P$ values were $>0.05$ ). ICS/ICS $+L A B A=$ inhaled corticosteroid/inhaled corticosteroid + long-acting beta2 agonists, LTRA = leukotriene receptor antagonist, DES = desensitization therapy, TCM = traditional Chinese medicine 
Table 3 Reasons for not following doctor's advice

\begin{tabular}{llc}
\hline Reasons & $n$ & Percentage (\%) \\
\hline Worrying about potential adverse effects & 131 & 25.1 \\
Believing it was the time to cease medicine & 129 & 24.8 \\
for well-controlled asthma & 42 & \\
Forgotten & 31 & 6.1 \\
Believing the medicine not working & 14 & 2.0 \\
Adverse effects occurred & 49 & 9.4 \\
Others & &
\end{tabular}

management of asthma in children 5 years and younger' separately. However, in the practice of asthma management, misdiagnosis of asthma does occur. Close follow-up should always be recommended to reexamine the treatment or even the diagnosis itself. Incidence rates for boys were higher than for girls before 9-year-old while incidence rates for boys were lower than for girls after 9-yearold [7]. We found the prevalence of asthma in boys was higher than in girls before adolescence, which is in agreement with results from other studies [6].

It should be noticed that, as a developing country, about a half of the family yearly income were 60,000120,000 yuan in our study. However, in the most costive year, asthma-related expenditure would be as high as more than 30,000 yuan in $0.9 \%$ of families. That was why $3.7 \%$ of guardians regarded the cost intolerable. In a systematic review, authors showed the mean annual cost/person, including direct and indirect cost on asthma management, was 151 to 4158 US dollars [8]. The cost of asthma was found to be strongly correlated with comorbidities, age, severity of disease, and some other factors [8]. We believe better control of asthma will help to decrease the cost of asthma.

Increased prevalence and heavy burden make early diagnosis and early treatment of asthma really important. In this study, we explored some factors that may be important for asthma development. We found the percentages of caesarean birth in asthma were higher than that in control group. In our country, the caesarean section rate rose dramatically from $3.4 \%$ in 1988 to $39.3 \%$ in 2008 [9]. Results about caesarean birth and asthma are conflicting. Caesarean birth was found associated with atopic diseases by altering exposure to maternal flora $[10,11]$. In a metaanalysis, authors found a $20 \%$ increase in the subsequent risk of asthma in children who had been delivered by Caesarean section [11]. However, childhood asthma in Malaysian children was not associated with delivery by caesarean section [12]. A recent study showed the previously reported association between caesarean birth and atopic disease may be due to confounding [13]. Whether the increasing rates of caesarean birth in China could partly explain the concomitant rise in asthma prevalence should be further demonstrated.
For children already diagnosed asthma, how to prevent the onset of acute asthma is still an interesting topic. In this study, we found respiratory tract infection was still a very important trigger of asthma attacks. Cold air, house dust, exercise, sea food and pollen were also important triggers. A significant negative correlation between asthma hospitalizations and daily mean temperature was found in an 8-year study [14]. Here we also found in children 6 years and older, some triggers happened more than that in children 5 years and younger. Most of them were inhaled triggers. This age-related difference should also raise the attention of patients and their parents to avoid the triggers.

We found concomitant allergic diseases, including atopic dermatitis, food allergy, allergic rhinitis, and urticaria had higher percentages in asthma children than in non-asthma children. Similar results were found in other literatures [15-19]. Asthma and rhinitis frequently coexist in the same subjects [20]. The prevalence of allergic rhinitis has generally increased in both adults and children over the last two decades in China [21]. Other allergic diseases had no exact data in comparing the prevalence in past decades in China. Further more, we found asthma children had higher probability that he or she once had one of these conditions, including drug allergy, food allergy and atopic dermatitis. So treat comorbidities like allergic rhinitis may decrease the possibility to develop to asthma or acute onset.

We also found exclusive breastfeeding within first 6 months and keeping animals had higher percentage in control group than in asthma patients. Most of results about breastfeeding and asthma encouraged breastfeeding. There were evidences that breastfeeding is protective for asthma (5-18 years) [22]. Breastfeeding, especially exclusively breastfeeding, was protective of asthma in Aboriginal children, which is consistent with what has been observed in non-Aboriginal children in Canada [23]. Three or more months of exclusive breastfeeding reduced the risk of asthmatic symptoms in the offspring of Latinas [24].

The treatment of ICS/ICS + LABA as a controller treatment was only used in less than a half in this study. The proportion of ICS/ICS + LABA using was lower than most studies in other areas [6]. This could be resulted from two reasons. One was that most of the patients were with mild asthma that only need treatment step 1 , which means only as-needed short-acting beta-agonist. However, the severity of asthma was not included in this study. The other reason was inadequate ICS treatment as recommended by GINA [1]. Inadequate ICS is one of independent risk factors for asthma exacerbations and also a risk factor for developing fixed airflow limitation [1]. Many parents refused to use corticosteroid even in inhaled way, for fear the potential adverse effects (Table 3). Poor inhaler technique obviously happens more often in children than in 
adults. The use of ICS, especially in small children, need proper devices and trained skills. Grandparents take care of children in most families in China. In those families, the complicated process of ICS using always make the family want to cease the medicine. Theses reasons may contribute to inadequate use of ICS/ICS + LABA in asthma children. LTRA, the optional orally intake medicines [1] occupied $36.4 \%$ of the treatment medicine. We found TCM was popular in treating asthma in our country. Use of TCM ranked the second place in asthma patients. In addition, we also found the adherence scored higher in TCM than in ICS/ICS + LABA and LTRA. Chinese herbal remedies for asthma such as anti-asthma herbal medicine intervention, modified Mai Men Dong Tang, Ding Chuan Tang et al. are used commonly in China. Since 2005, English language publications have reported results of double-blind, placebo-controlled clinical studies investigating efficacy and safety of TCM for asthma. Evidences from clinical studies have supported beneficial effects of TCM herbal therapy on asthma [25].

There were some limitations to our study. In investigating of side effects, we could not include the effect of height or body weight growth as this was a cross-sectional survey. Additionally, in answering some questions about things happened many years ago, recall bias occurred. This happened more easily in big children when answering about pregnancy, breastfeeding, and so on. In this study, we did not include the severity assessment which could have helped us to analyze some important aspects like the choose of therapies.

\section{Conclusions}

In conclusion, we conducted an epidemiology study in Hangzhou. The prevalence of childhood asthma was $4.8 \%$. Asthma was an economic and social burden to both children and guardians. Respiratory tract infection was the most common trigger of asthma attacks (85.1\%). Other common causes included cold air, house dust, exercise, fish and shrimp, pollen, and et al. In children 6 years and older, some triggers happened more than that in children 5 years and younger. The triggers were exercise, emotional changes and five inhaled causes, including house dust, pollen, renovation works in the home, mosquito-repellent incense, and pets. Risk factors of asthma development may include caesarean birth, personal history of allergy (atopic dermatitis, drug allergy and food allergy), and concomitant allergic diseases (atopic dermatitis, food allergy, allergic rhinitis, and urticaria). Exclusive breastfeeding within first 6 months and keeping animals might be protecting factor of asthma development. The used of ICS/ICS + LABA, TCM, LTRA, and desensitization therapy was $46.2 \%, 44.2 \%, 36.4 \%$ and $7.2 \%$. The adherence scored higher in TCM than in ICS/ ICS + LABA and LTRA.

\section{Abbreviations}

GINA: Global Initiative for Asthma; ICS: Inhaled corticosteroid; ISAAC: International Study of Asthma and Allergies in Childhood; LABA: Long-acting beta2 agonists; NEAAC: National Epidemiology study of Asthma and Allergies in China;

TCM: Traditional Chinese medicine; LTRA: Leukotriene receptor antagonist

\section{Acknowledgements}

The authors thank all children and guardians involved in the study. We also thank Yanan Feng and Jian Shen from Hangzhou first people's hospital for collecting data.

\section{Funding}

No funding.

\section{Availability of data and materials}

Additional information could be found here: Xu D, Wang Y, Chen Z, Li S, Cheng Y, Zhang L, Zhao L. Data from: Prevalence and risk factors for asthma among children aged 0-14 years in Hangzhou: a cross-sectional survey. Dryad Digital Repository. http://dx.doi.org/10.5061/dryad.0194k.

\section{Authors' contributions}

DX was involved in the design and data analysis of this study and drafted the manuscript. YW was responsible for oversight of the whole study and edited the manuscript. ZC conceived of the review and edited the manuscript. ZC is the guarantor. SL, YC, LZ and $L Z$ collected and analyzed the data. All authors read and approved the final manuscript.

\section{Competing interests}

The authors declare that they have no competing interests.

Consent for publication

Not applicable.

\section{Ethics approval and consent to participate}

The study was approved by the Ethics Committee of Children's Hospital, Zhejiang University School of Medicine. Each questionnaire was approved by the child's guardian

\section{Author details}

${ }^{1}$ Department of Pulmonology, The Children's Hospital of Zhejiang University School of Medicine, 3333 Binsheng Road, Hangzhou 310003, Zhejiang Province, China. 'Department of Internal Medicine, Hangzhou Children's Hospital, 201 Wenhui Road, Hangzhou 310014, Zhejiang Province, China. ${ }^{3}$ Department of Pediatric, Yueqing People's Hospital, 338 Qingyuan Road, Yueqing, Wenzhou 325600, Zhejiang Province, China.

Received: 5 January 2016 Accepted: 21 September 2016

Published online: 27 September 2016

\section{References}

1. The Global Strategy for Asthma Management and Prevention, Global Initiative for Asthma (GINA) 2014. Available from: http://www.ginasthma.org/.

2. Chen $Y Z$. A nationwide survey in China on prevalence of asthma in urban children. Zhonghua Er Ke Za Zhi. 2003;41(2):123-7.

3. The Global Strategy for Asthma Management and Prevention, Global Initiative for Asthma (GINA) 2010. Available from: http://www.ginasthma.org/.

4. Yunginger JW, Reed CE, O'Connell EJ, Melton 3rd L, O'Fallon WM, Silverstein MD. A community-based study of the epidemiology of asthma. Incidence rates, 1964-1983. Am Rev Respir Dis. 1992;146(4):888-94.

5. Haahtela T, Tuomisto LE, Pietinalho A, Klaukka T, Erhola M, Kaila M, Nieminen MM, Kontula E, Laitinen LA. A 10 year asthma programme in Finland: major change for the better. Thorax. 2006;61(8):663-70.

6. Karlstad O, Nafstad P, Tverdal A, Skurtveit S, Furu K. Prevalence, incidence and persistence of anti-asthma medication use in 2- to 29-year-olds: a nationwide prescription study. Eur J Clin Pharmacol. 2010;66(4):399-406.

7. Engelkes M, Janssens HM, de Ridder MA, de Jongste JC, Sturkenboom MC, Verhamme KM. Time trends in the incidence, prevalence and age at diagnosis of asthma in children. Pediatr Allergy Immunol. 2015;26(4):367-74.

8. Bahadori K, Doyle-Waters MM, Marra C, Lynd L, Alasaly K, Swiston J, Fitzgerald JM. Economic burden of asthma: a systematic review. BMC Pulm Med. 2009;9(1):24. 
9. Feng $X \mathrm{~L}, \mathrm{Xu} \mathrm{L}, \mathrm{Guo} Y$, Ronsmans $C$. Factors influencing rising caesarean section rates in China between 1988 and 2008. Bull World Health Organ. 2012;90(1):30-9. 39A.

10. Adams M, Doull I. Birth by caesarean section and asthma. Clin Exp Allergy. 2008;38(4):554-6.

11. Thavagnanam S, Fleming J, Bromley A, Shields MD, Cardwell CR. A metaanalysis of the association between Caesarean section and childhood asthma. Clin Exp Allergy. 2008;38(4):629-33.

12. Nathan AM, de Bruyne J, Khalid F, Arumugam K. Caesarean section and asthma in Malaysian children: a case-control study. Asian Pac J Allergy Immunol. 2012;30(3):204-8.

13. Hancox RJ, Landhuis CE, Sears MR. Forceps birth delivery, allergic sensitisation and asthma: a population-based cohort study. Clin Exp Allergy. 2013;43(3):332-6.

14. Zhang Y, Peng L, Kan H, Xu J, Chen R, Liu Y, Wang W. Effects of meteorological factors on daily hospital admissions for asthma in adults: a time-series analysis. PLoS One. 2014;9(7):e102475.

15. Bantz SK, Zhu Z, Zheng T. The Atopic March: Progression from Atopic Dermatitis to Allergic Rhinitis and Asthma. J Clin Cell Immunol. 2014;5(2):202.

16. Sanchez J, Paez B, Macias A, Olmos C, de Falco A. Atopic dermatitis guideline. Position paper from the Latin American Society of Allergy, Asthma and Immunology. Rev Alerg Mex. 2014;61(3):178-211.

17. Tan RA, Corren J. The relationship of rhinitis and asthma, sinusitis, food allergy, and eczema. Immunol Allergy Clin North Am. 2011;31(3):481-91.

18. Irani AM. Food allergy and increased asthma morbidity in a school-based inner-city asthma study. Pediatrics. 2014;134 Suppl 3:S166-7.

19. Ibiapina CC, Sarinho ES, da Cruz Filho AA, Camargos PA. Rhinitis, sinusitis and asthma: hard to dissociate. J Bras Pneumol. 2006;32(4):357-66.

20. Bousquet J, Schunemann HJ, Samolinski B, Demoly P, Baena-Cagnani CE, Bachert C, Bonini S, Boulet LP, Bousquet PJ, Brozek JL, Canonica GW, Casale TB, Cruz AA, Fokkens WJ, Fonseca JA, van Wijk RG, Grouse L, Haahtela T, Khaltaev N, Kuna P, Lockey RF, Lodrup Carlsen KC, Mullol J, Naclerio R, O'Hehir RE, Ohta K, Palkonen S, Papadopoulos NG, Passalacqua G, Pawankar R, Price D, Ryan D, Simons FE, Togias A, Williams D, Yorgancioglu A, Yusuf OM, Aberer W, Adachi M, Agache I, Ait-Khaled N, Akdis CA, Andrianarisoa A, Annesi-Maesano I, Ansotegui IJ, Baiardini I, Bateman ED, Bedbrook A, Beghe B, Beji M, Bel EH, Ben Kheder A, Bennoor KS, Bergmann KC, Berrissoul F, Bieber T, Bindslev Jensen C, Blaiss MS, Boner AL, Bouchard J, Braido F, Brightling CE, Bush A, Caballero F, Calderon MA, Calvo MA, Camargos PA, Caraballo LR, Carlsen KH, Carr W, Cepeda AM, Cesario A, Chavannes NH, Chen YZ, Chiriac AM, Chivato Perez T, Chkhartishvili E, Ciprandi G, Costa DJ, Cox L, Custovic A, Dahl R, Darsow U, De Blay F, Deleanu D, Denburg JA, Devillier P, Didi T, Dokic D, Dolen WK, Douagui H, Dubakiene R, Durham SR, Dykewicz MS, El-Gamal Y, El-Meziane A, Emuzyte R, Fiocchi A, Fletcher M, Fukuda T, Gamkrelidze A, Gereda JE, Gonzalez Diaz S, Gotua M, Guzman MA, Hellings PW, Hellquist-Dahl B, Horak F, Hourihane JO, Howarth P, Humbert M, Ivancevich JC, Jackson C, Just J, Kalayci O, Kaliner MA, Kalyoncu AF, Keil T, Keith PK, Khayat G, Kim YY, Koffi N'goran B, Koppelman GH, Kowalski ML, Kull I, Kvedariene V, Larenas-Linnemann D, Le LT, Lemiere C, Li J, Lieberman P, Lipworth B, Mahboub B, Makela MJ, Martin F, Marshall GD, Martinez FD, Masjedi MR, Maurer M, Mavale-Manuel S, Mazon A, Melen E, Meltzer EO, Mendez NH, Merk H, Mihaltan F, Mohammad Y, Morais-Almeida M, Muraro A, Nafti S, Namazova-Baranova L, Nekam K, Neou A, Niggemann B, Nizankowska-Mogilnicka E, Nyembue TD, Okamoto Y, Okubo K, Orru MP, Ouedraogo S, Ozdemir C, Panzner P, Pali-Scholl I, Park HS, Pigearias B, Pohl W, Popov TA, Postma DS, Potter P, Rabe KF, Ratomaharo J, Reitamo S, Ring J, Roberts R, Rogala B, Romano A, Roman Rodriguez M, Rosado-Pinto J, Rosenwasser L, Rottem M, Sanchez-Borges M, Scadding GK, SchmidGrendelmeier P, Sheikh A, Sisul JC, Sole D, Sooronbaev T, Spicak V, Spranger O, Stein RT, Stoloff SW, Sunyer J, Szczeklik A, Todo-Bom A, Toskala E, Tremblay $Y$, Valenta R, Valero AL, Valeyre D, Valiulis A, Valovirta E, Van Cauwenberge $P$, Vandenplas $O$, van Weel C, Vichyanond P, Viegi G, Wang DY, Wickman M, Wohrl S, Wright J, Yawn BP, Yiallouros PK, Zar HJ, Zernotti ME, Zhong N, Zidarn M, Zuberbier T, Burney PG, Johnston SL, Warner JO. Allergic Rhinitis and its Impact on Asthma (ARIA): achievements in 10 years and future needs. J Allergy Clin Immunol. 2012;130(5):1049-62.

21. Zhang $Y$, Zhang L. Prevalence of allergic rhinitis in china. Allergy, Asthma Immunol Res. 2014:6(2):105-13.

22. Lodge CJ, Tan DJ, Lau M, Dai X, Tham R, Lowe AJ, Bowatte G, Allen KJ Dharmage SC. Breastfeeding and asthma and allergies: a systematic review and meta-analysis. Acta Paediatr. 2015;104(467):38-53.

23. Ye M, Mandhane PJ, Senthilselvan A. Association of breastfeeding with asthma in young Aboriginal children in Canada. Can Respir J. 2012;19(6):361-6.
24. Bandoli G, von Ehrenstein OS, Flores ME, Ritz B. Breastfeeding and Asthmatic Symptoms in The Offspring of Latinas: The Role of Maternal Nativity. J Immigr Minor Health. 2015;17(6):1739-45.

25. Li XM, Brown L. Efficacy and mechanisms of action of traditional Chinese medicines for treating asthma and allergy. J Allergy Clin Immunol. 2009; 123(2):297-306. quiz 307-308.

\section{Submit your next manuscript to BioMed Central and we will help you at every step:}

- We accept pre-submission inquiries

- Our selector tool helps you to find the most relevant journal

- We provide round the clock customer support

- Convenient online submission

- Thorough peer review

- Inclusion in PubMed and all major indexing services

- Maximum visibility for your research

Submit your manuscript at www.biomedcentral.com/submit
C Biomed Central 